\title{
Optimization of enzymatic synthesis of ethyl hexanoate in a solvent free system using response surface methodology (RSM)
}

https://doi.org/10.1515/boca-2018-0002

Received December 4, 2017; accepted March 14, 2018

\begin{abstract}
The present paper demonstrates application of biocatalysis to the synthesis of ethyl hexanoate, i.e. pineapple flavour ester, in a solvent free system. In order to evaluate the effect of various process parameters on reaction conversion, response surface methodology (RSM) complemented by central composite design (CCD) was employed. A maximum conversion of $88.57 \%$ was obtained while changing one factor at a time, at optimum conditions of temperature $\left(50^{\circ} \mathrm{C}\right)$, enzyme dose $(2 \%)$, molar ratio acid to alcohol (1:3), speed of agitation $250 \mathrm{rpm}$ and reaction time of $120 \mathrm{~min}$. Based on this RSM study, the optimum predicted conditions were: 1:3.39 alcohol to acid ratio, 2.35\% enzyme loading and $48.83{ }^{\circ} \mathrm{C}$, for a predicted conversion of $90.99 \%$. The activation energy for the enzymatic esterification was determined and calculated to be $25.76 \mathrm{~kJ} / \mathrm{mol}$. The positive values of Gibbs-free energy $(\Delta \mathrm{G})$, enthalpy $(\Delta \mathrm{H})$ and negative value of entropy $(\Delta S)$ revealed that the esterification reaction was non-spontaneous and an endothermic reaction. The reaction seems to follow bi-substrate Ping Pong $\mathrm{Bi} \mathrm{Bi}$ mechanism with inhibition by both substrates.
\end{abstract}

Keywords: pineapple flavour, lipase, thermodynamics, kinetics, response surface methodology

\section{Introduction}

In recent years, there has been an increasing demand for flavoured compounds in industrial sectors, especially food and beverage, cosmetic and pharmaceutical industries

\footnotetext{
*Corresponding author: Virendra K. Rathod, Department of Chemical Engineering, Institute of Chemical Technology, Matunga (E), Mumbai-400019, India, E-mail: vk.rathod@ictmumbai.edu.in Sarita D. Gawas, Nidya Lokanath, Department of Chemical Engineering, Institute of Chemical Technology, Matunga (E), Mumbai-400019, India
}

[1-4]. These compounds are generally short chain alkyl esters which are characterized by their strong fruity flavour and fragrance. Ethyl hexanoate is one of these short chain ethyl esters, with an apple-pineapple flavour $[5,6]$. Although most of the flavours are preferred to extract from their natural sources, they are not generally used due to the high cost of raw material and low extraction yield. There are numerous ways for the synthesis of organic esters and most of them have been briefly studied by Yadav and Mehta [7]. Esters are conventionally synthesized by esterification of carboxylic acid with an alcohol, using sulfuric acid or para-toluene-sulfonic acid as catalysts. However, the presence of an acid catalyst in the final product makes it unacceptable by the end-users of food and pharmaceutical industries. On the other hand, the enzymatically synthesized flavours and fragrances in a solvent free system are labelled as 'natural' and have huge market demand [9-11]. Furthermore, enzymes give high quality products and also consume lower energy during the reaction. Additionally, the enzyme-catalysed production of flavours and fragrances using solvent free system is preferred over the use of organic solvents. Reactions performed under solvent-free conditions can decrease the production cost as well as the number of downstream steps and thus facilitate its industrial application [12,13].

Lipases are found to be very efficient catalysts for esterification reactions. Among various lipases, Candida antarctica lipase-B (CALB), is found to exhibit high substrate specificity. For the last few decades, the enzymatic synthesis of short chain esters has been studied by different scientists using response surface methodology (RSM) [14-17]. RSM is an efficient statistical technique which has been successfully applied to study and optimize the enzymatic synthesis of various esters $[18,19]$. Recent large demands in natural pineapple flavour has forced many researchers to work on its production using enzyme catalyst. In literature, the synthesis of hexanoic acid esters by transesterification of ethyl caprate 
in n-hexane using immobilized lipase from $R$. miehei with $96 \%$ conversion in $96 \mathrm{~h}$ at $50{ }^{\circ} \mathrm{C}$, was reported [20]. Ethyl hexanoate was also synthesized with Rhizopus chinesis CCTCC M201021 cells in non-aqueous phase (hexane) and reported a conversion of $96.2 \%$ after $72 \mathrm{~h}$ [5]. Han et al. (2009) and Jin et al. (2012) described the synthesis of ethyl caproate catalysed by CALB-displaying $S$. cerevisiae or Pichia pastoris whole-cells in presence of a solvent (heptane), respectively [21, 22]. Thus, all the reported experiments on enzyme catalysed pineapple flavour synthesis mostly utilized solvents and also required long reaction times, making the process tedious and costly.

The present work focuses on Novozym 435 catalysed synthesis of ethyl hexanoate in solvent free conditions, with optimization carried out using a central composite design and RSM analysis. The various parameters affecting the synthesis, such as the substrate molar ratio, enzyme loading and the reaction temperature were studied. The bi-substrate kinetic mechanisms namely Ordered $\mathrm{Bi}-\mathrm{Bi}$ mechanism and Ping Pong Bi Bi mechanism were tested for the validation of the experimental data.

\section{Materials and methods}

\subsection{Materials}

The Novozym 435 was obtained as gift samples from Novo Nordisk, Denmark. Novozym 435 is a Candida antarctica lipase immobilized on macroporous polyacrylic resin beads and the nominal activity of the catalytic preparation was 7000 PLU units per g dry weight (Propyl laurate synthesis). One PLU enzyme unit corresponds to the synthesis of 1 micromole propyl laurate per minute per $\mathrm{g}$ of immobilized enzyme at $60{ }^{\circ} \mathrm{C}$ from lauric acid and 1-propanol.

The hexanoic acid, ethanol and $n$-decane were purchased from S.D. Fine Pvt. Ltd, Mumbai. The potassium hydroxide, sodium hydroxide, phenolphthalein indicator and ethanol 96\% were purchased from Thomas Baker (Chemicals) Pvt. Ltd., Mumbai. All other chemicals used in this study were of analytical grade and used further without purification.

\subsection{Methods}

\subsubsection{Enzymatic esterification}

The experimental setup consisted of a glass reactor of 50 $\mathrm{mL}$ capacity equipped with three baffles and a six bladed turbine impeller. The complete reactor assembly was dipped in a water bath to maintain the reactor mixture at a desired temperature with an accuracy of $\pm 1^{\circ} \mathrm{C}$. The esterification reaction was carried out by chagrining known amount of hexanoic acid $(0.05 \mathrm{M})$ and ethanol $(0.05)$ in the reactor. The reaction was initiated by adding the Novozym 435 ( $2 \% \mathrm{w} / \mathrm{w}$ of total weight of substrate) as a catalyst and molecular sieves $(6 \% \mathrm{w} / \mathrm{w}$ of total weight of substrate) as a scavenger for water produced during the reaction. The reaction mixture was stirred at $250 \mathrm{rpm}$ and samples were withdrawn at known time internals. The samples were further analysed by a titrimetric method and the product was confirmed by gas chromatography. The real molar concentrations of hexanoic acid [A] and ethanol [B] were used directly in solvent free system as 8.0 $\mathrm{M}$ and $17.13 \mathrm{M}$, respectively. The equimolar (4.86 M) mixture of both the reactants $[\mathrm{A}]$ and $[\mathrm{B}]$ solution requires [A] $6.2 \mathrm{~cm}^{3}$ and [B] $2.9 \mathrm{~cm}^{3}$, respectively. In the same way, all reaction mixtures were prepared based on a predefined molar ratio.

\subsection{Analysis}

\subsubsection{Titrimetric Analysis}

The progress of esterification was determined by measuring the unreacted hexanoic acid in the reaction mixture by titration with $0.01 \mathrm{~N} \mathrm{KOH}$ solution. The phenolphthalein and ethanol was used as indicator and a quenching agent, respectively. All the samples were titrated thrice for accuracy. The acid value was calculated by using following equation:

Acid value $=\frac{56.1 \times \text { Normality of } \mathrm{KOH}(\mathrm{M}) \times \mathrm{B}(\mathrm{mL})}{\text { Weight of sample }(\mathrm{g})}$

Where $\mathrm{B}$ is the burette reading in $\mathrm{mL}$. The conversion (\%) was calculated as follows:

Conversion $(\%)=\frac{\text { Vol KOH with enzyme }- \text { Vol KOH without enzyme }}{\text { Vol KOH without enzyme }} \times 100$

\subsubsection{Gas chromatography}

The percentage conversion of ethyl hexanoate was confirmed by using GC (Chemito GC 8610) equipped with a Flame ionization detector (FID), a packed column OV-107 (1/8" diameter, $3 \mathrm{~m}$ length) and nitrogen as the carrier gas at the rate of $10 \mathrm{ml} / \mathrm{min}$, air and hydrogen was used at a flow rate of $300 \mathrm{ml} / \mathrm{min}$ and $10 \mathrm{ml} / \mathrm{min}$, respectively. The oven temperature programme was as follows: $50{ }^{\circ} \mathrm{C}$ for $1 \mathrm{~min}, 5{ }^{\circ} \mathrm{C} / \mathrm{min}$ increased up to $150{ }^{\circ} \mathrm{C} ; 10^{\circ} \mathrm{C} / \mathrm{min}$ up to $230^{\circ} \mathrm{C}$; then steady temperature for $10 \mathrm{~min}$. The 
injector and detector temperature were $200^{\circ} \mathrm{C}$ and $250^{\circ} \mathrm{C}$, respectively. The gas chromatography method was used for identification of the product.

\subsubsection{Determination of initial rates of reaction}

Initial rates of esterification were determined at various reaction conditions, depending on the molar ratio. The molar ratio of acid to alcohol varied from 3:1 to 1:4 in integral successions. The temperature was maintained at $60{ }^{\circ} \mathrm{C}$ with $5 \%(\mathrm{w} / \mathrm{w})$ enzyme loading. Reactions were carried out for $120 \mathrm{~min}$ at $250 \mathrm{RPM}$. Aliquots of the reaction mixture were taken sequentially and analysed by titrimetric analysis as discussed above. Conversion data for $<10 \%$ conversion was used to determine initial reaction rates by plotting conversion verses time profiles. Experiments were carried out by keeping the concentration of one of the substrates constant and was carried out in a solvent free system in either a specific or random manner, to form a complex varying the concentration of the other and vice versa.

\subsubsection{Kinetics and mechanisms of the esterification reaction}

To determine the kinetic parameters of the esterification, several experiments were carried out by varying the ratio of hexanoic acid to ethanol from 3:1 to 1:4. As per Ping Pong Bi Bi mechanism, two substrates; hexanoic acid [A] and ethanol $[\mathrm{B}]$ were initially bound to the immobilized lipase [E] to form a complex [AEB]. This ternary complex then isomerises to form another complex [EPQ], which releases product $[\mathrm{P}]$ and water $[\mathrm{Q}]$. Kinetic parameters were determined graphically. The general rate equation for the Ping Pong Bi Bi mechanism, can be proposed as follows [23]:

$$
v_{0}=\frac{V_{\max [A][B]}}{[A][B]+K_{B}[A]+\left(1+[A] / K_{i A}\right)+K_{A}[B]\left(1+[B] / K_{i B}\right)}
$$

And for the Ordered Bi Bi mechanism [23]:

$$
v_{0}=\frac{V_{\max [A][B]}}{[A][B]+K_{B}[A]+K_{A}[B]\left(1+[B] / K_{i A}\right)+K_{i A} K_{B}\left(1+[B] / K_{i}\right)}
$$

Where, $v_{0}$ is the initial reaction rate; $V_{\max }$ is the maximum reaction rate; $[\mathrm{A}]$ is the hexanoic acid concentration and $[\mathrm{B}]$ the ethanol concentration; $\mathrm{K}_{\mathrm{A}}$ and $\mathrm{K}_{\mathrm{B}}$ are the Michaelis Menten constants of hexanoic acids and ethanol; $\mathrm{K}_{\mathrm{iA}}$ and $\mathrm{K}_{\mathrm{iB}}$ are the inhibition coefficients of the acid and alcohol, respectively.

\subsubsection{Modelling Studies through RSM}

The solvent free synthesis of ethyl hexanoate was carried out by using immobilized Candida antartica lipase. To evaluate optimum conditions, the reaction was studied by one factor at a time. The effect of time, enzyme loading, temperature, molar ratio and speed of agitation was studied in a solvent free system. The lipase catalyzed synthesis of flavour involves interactions among several variables, therefore traditional methods were inefficient for optimization of the reaction. Response surface methodology (RSM) is a statistical model approach for empirical modelling which evaluates the effect of individual and interaction effects of the process parameters on the corresponding response value. In preliminary single factor method, the molar ratio, enzyme loading and temperature were found as significant parameters affecting esterification conversion, which were further selected for response surface methodology. Design Expert 7.0 software was used for designing the experiments and for analysis of the data. According to a central composite design (CCD), 20 experiments were performed in this reaction study to find the optimum combination and effect of parameters on the enzymatic synthesis of ethyl hexanoate. Table 1 shows the independent factors, levels and experimental design in terms of coded and uncoded variables [17,24]. Experimental data from the CCD was analysed using regression analysis and fitted to a secondorder polynomial model in order to identify all possible interactions of selected factors with a response function as

Table 1. Variables and their levels employed in the central composite design method for optimal ethyl hexanoate production in solvent-free system

\begin{tabular}{lccc}
\hline & & Levels & \\
\hline Variable & $\mathbf{- 1}$ & $\mathbf{0}$ & $\mathbf{+ 1}$ \\
\hline Molar ratio (acid: alcohol) & $1: 2$ & $1: 3$ & $1: 4$ \\
Enzyme loading $(\%$ w/w) & 1.5 & 2 & 2.5 \\
Temperature $\left({ }^{\circ} \mathrm{C}\right)$ & 40 & 50 & 60 \\
\hline
\end{tabular}


follows:

$$
Y=b_{0}+\sum_{i=1}^{n} b_{i} X_{i}+\sum_{i=1}^{n} b_{i i} X_{i}^{2}+\sum_{i=1}^{n-1} \sum_{j=i+1}^{n} b_{i j} X_{i} X_{j}
$$

Where $\mathrm{Y}$ is the response (percentage conversion), $\mathrm{b}_{\mathrm{o}}$ is the constant coefficient, $b_{i}, b_{i i}, b_{i j}$ are coefficients for the linear, quadratic, and interaction effects, respectively; $X i$ and $X j$ are the independent variables. The fit of the model was evaluated by means of two diagnostic residuals: the multiple or adjusted coefficient of determination $\left(R^{2}\right.$ and $\mathrm{R}^{2} a d j$ respectively) and analysis of variance (ANOVA).

\subsubsection{Determination of activation energy and thermodynamic parameters}

The Arrhenius equation gives a relationship between the specific reaction rate constant $(\mathrm{k})$, absolute temperature (T) and the energy of activation $\left(\mathrm{E}_{\mathrm{a}}\right)$ as:

$$
K=A \exp \left[-\frac{E_{a}}{R T}\right]
$$

Where $\mathrm{A}$ is the frequency factor and $\mathrm{R}$ is the universal gas constant $(\mathrm{J} / \mathrm{mol} / \mathrm{K})$. This equation is rewritten as [25].

$$
\ln k=\left[-\frac{E_{a}}{R T}\right]+\ln A
$$

Three reaction temperatures were used (as mentioned in Table 1) in our statistical experimental design. Experiments were conducted using optimum values of enzyme loading and ethanol to hexanoic acid molar ratio (as determined from the statistical experimental design) at these three reaction temperatures. The Arrhenius Plot of $\ln (\mathrm{k})$ versus reciprocal absolute temperature $(1 / \mathrm{T})$ can be used to determine activation energy.

The thermodynamic parameters for enzymatic esterification were determined using the Eyring equation as follows [26] :

$$
\begin{aligned}
& \ln \frac{k}{T}=\left[\frac{-\Delta H}{R}\right]\left[\frac{1}{T}\right]+\ln \left[\frac{k_{b}}{h}\right]+\frac{\Delta S}{R} \\
& \Delta H=E a-R T \\
& \Delta G=\Delta H-T \Delta S
\end{aligned}
$$

Where $\mathrm{h}=$ Planck's constant $\left(6.626 \times 10^{-34} \mathrm{~J} . \mathrm{s}\right), \mathrm{k}_{\mathrm{b}}=$ Boltzmann constant $\left(1.381 \times 10^{-23} \mathrm{~J} / \mathrm{K}\right), \mathrm{k}=$ rate constant at temperature $\mathrm{T}, \Delta \mathrm{H}=$ Enthalpy of activation, $\Delta \mathrm{S}=$ Entropy of activation, $R=$ universal gas constant, and $\Delta \mathrm{G}=$ Gibbs free energy. The values obtained from Arrhenius analysis can be substituted into the above set of equations to yield thermodynamic parameters, viz. $\Delta \mathrm{H}, \Delta \mathrm{S}$ and $\Delta \mathrm{G}$ in association with enzymatic esterification reaction.

\section{Results and discussion}

\subsection{Effect of one factor at a time experiments for ethyl hexanoate synthesis}

\subsubsection{Effect of reaction time}

Figure 1 represents the time progression for the enzymatic esterification of ethanol and hexanoic acid with 1:1 substrate ratio by Novozym $435(2 \%)$ at $50{ }^{\circ} \mathrm{C}$ up to 150 min. It was observed that percentage conversion of ethyl hexanoate reached up to $73.6 \%$ in the initial $120 \mathrm{~min}$ and a marginal change in conversion was observed after $120 \mathrm{~min}$. This attributes to the reversible nature of the esterification reaction. Similarly, the slow rate of reaction after the initial hours was due to accumulation of the reaction product on the active site of enzyme that reduces the surface area/active site available for the reaction. A similar trend was observed in previous enzymatic esterification reactions [27,28]. Thus, all experiments were performed for 120 minutes to study the various parameters. The ethyl hexanoate production was confirmed by GC analysis and illustrative chromatograms for $0 \mathrm{~min}$ and $120 \mathrm{~min}$ reaction are represented in Figure 2(a) and 2(b), respectively.

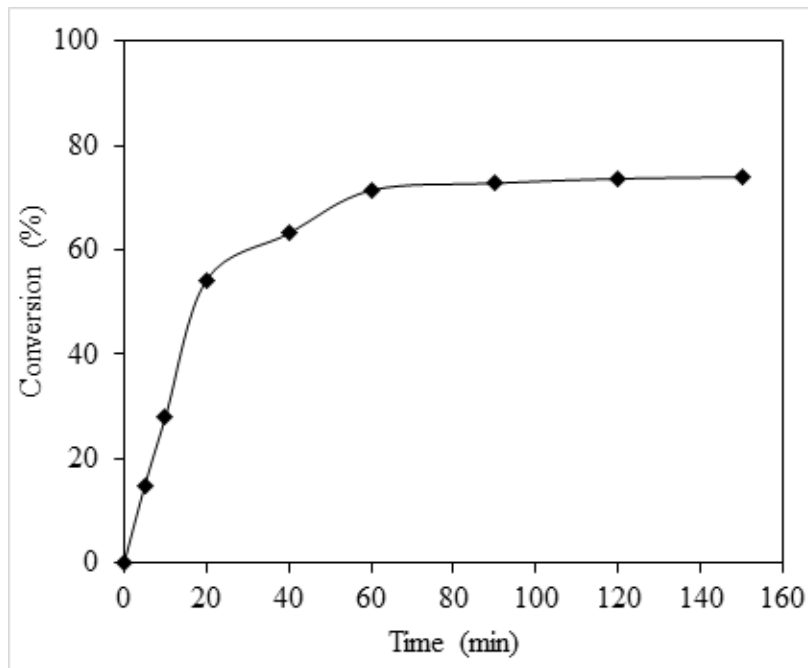

Figure 1. Effect of reaction time on \% conversion at hexanoic acid to ethanol ratio $1: 1$, temperature $50^{\circ} \mathrm{C}$, agitation speed $250 \mathrm{rpm}$, enzyme loading $2 \%$, molecular sieves $6 \%$

\subsubsection{Effect of substrate ratio}

The molar ratio of hexanoic acid to ethanol was varied from 3:1 to $1: 4$ at an enzyme loading of $2 \%(w / w)$, temperature of $50 \stackrel{\circ}{\circ}$ and 250 RPM. Modifying the ratio 
a

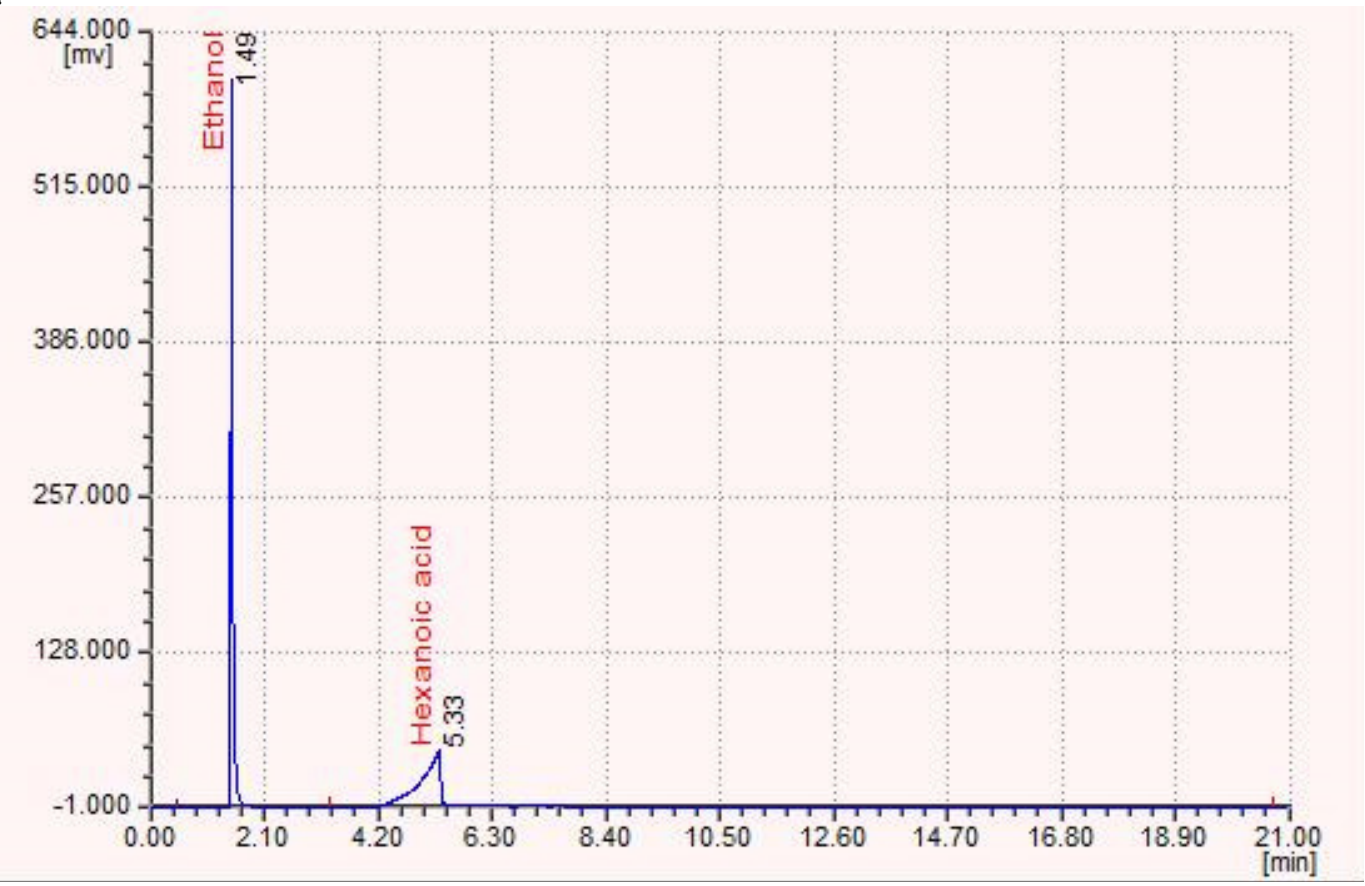

b

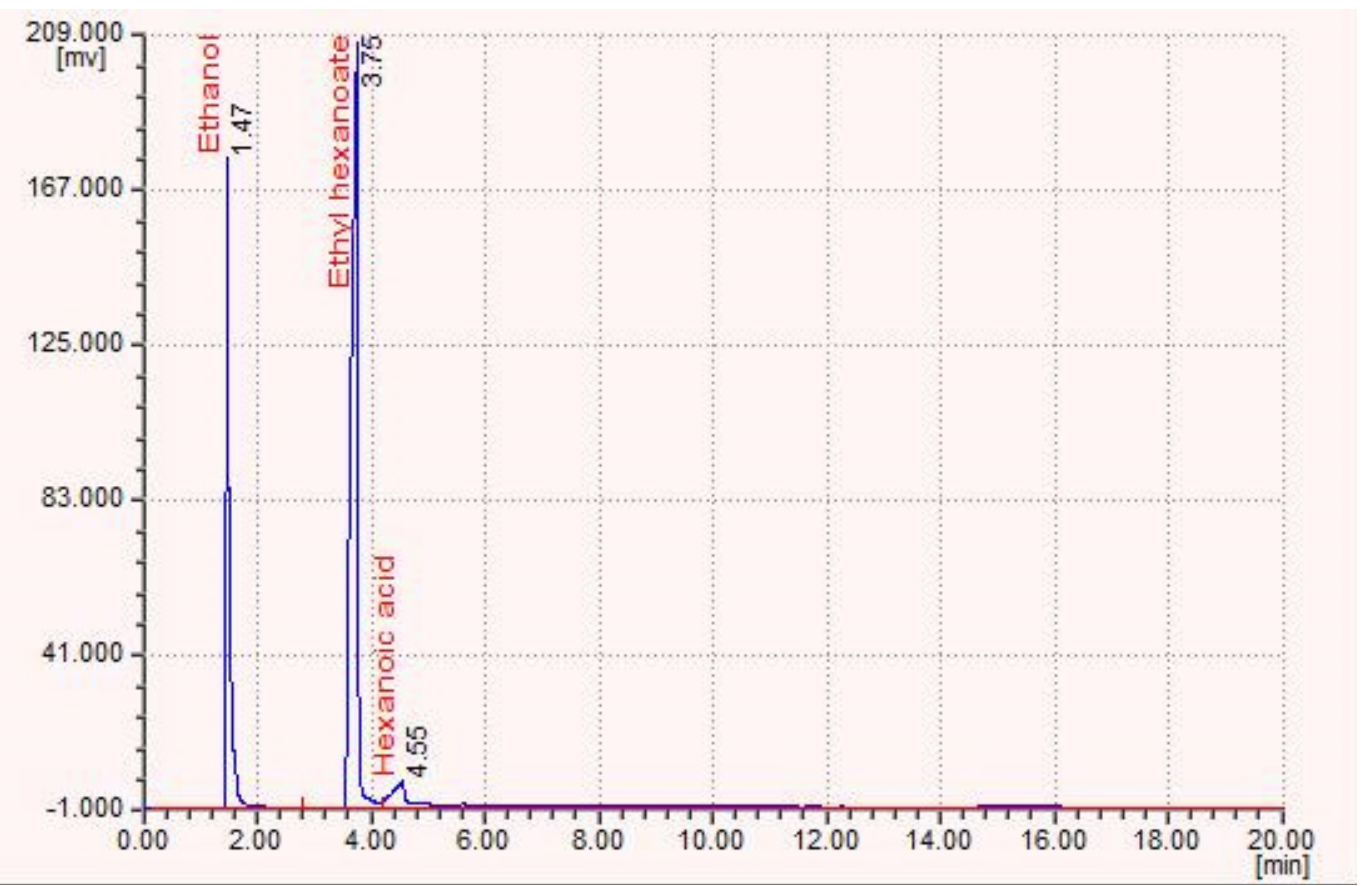

Figure 2 (a). The illustrative chromatogram of ethyl hexanoate synthesis for 0 min reaction and (b) The illustrative chromatogram of ethyl hexanoate synthesis at $120 \mathrm{~min}$ reaction.

of hexanoic acid to ethanol from 1:1 to 1:4, increases conversion i.e $88.57 \%$ (Figure 3a) and the rate i.e. $0.35 \mathrm{M} /$ $\mathrm{min} / \mathrm{g}$-enzyme (Figure $3 \mathrm{~b}$ ) of the reaction up to a ratio of 1:3. The active sites of enzymes are occupied by ethanol at 1:3 ratio and excess ethanol may not increase the rate of the reaction since no active sites are available beyond certain level of ethanol [29]. By increasing ratio to 1:4, the rate of reaction $(0.28 \mathrm{M} / \mathrm{min} / \mathrm{g}$-enzyme $)$ and conversion decreases; which can be attributed to the inhibitory effect of ethanol on the enzyme. Further, the amount of hexanoic acid was increased to obtain the ratio of hexanoic acid to ethanol as 2:1 to 3:1. It has been found that the rate of reaction and conversion decreased with higher hexanoic acid (Figure.3a-3b). This might be due to the substrate becoming adsorbed on the catalyst active site or inhibition of catalyst because of abundance substrate [30]. This kind 
of inhibition by hexanoic acid was also reported by earlier report [20]. In order to interpret the effects with regard to the kinetics of the reaction, Ping Pong $\mathrm{Bi} \mathrm{Bi}$ and Ordered $\mathrm{Bi} \mathrm{Bi}$ mechanism studies were conducted as discussed in section 3.6.

\subsubsection{Effect of temperature}

Experiments were also performed to identify the optimum reaction temperature and it was found that as the temperature increases from $40{ }^{\circ} \mathrm{C}$ to $50{ }^{\circ} \mathrm{C}$, the conversion increases (Figure S1). It was observed that maximum conversion of $88.57 \%$ was obtained at $50{ }^{\circ} \mathrm{C}$ which decreased to $80.2 \%$ at $60{ }^{\circ} \mathrm{C}$. This may be attributed to the denaturation of enzyme at high temperature [30].

\subsubsection{Effect of enzyme loading}

The effect of enzyme loading was studied with loadings from $1.5 \%$ to $2.5 \%(\mathrm{w} / \mathrm{w})$ as showed in Figure S2. The experiments were carried out by varying the amount of enzyme loading at fixed molar ratio 1:3 of hexanoic acid to ethanol, temperature of $50{ }^{\circ} \mathrm{C}$ and at $250 \mathrm{rpm}$. The overall conversion increased to $88.57 \%$ with an increase in the enzyme loading up to $2 \%$. However, further increase in enzyme loading (2.5\%) declined the percentage conversion to $82.64 \%$ as excess amount of enzyme may increase the viscosity of solution and reduce the mass transfer [29].

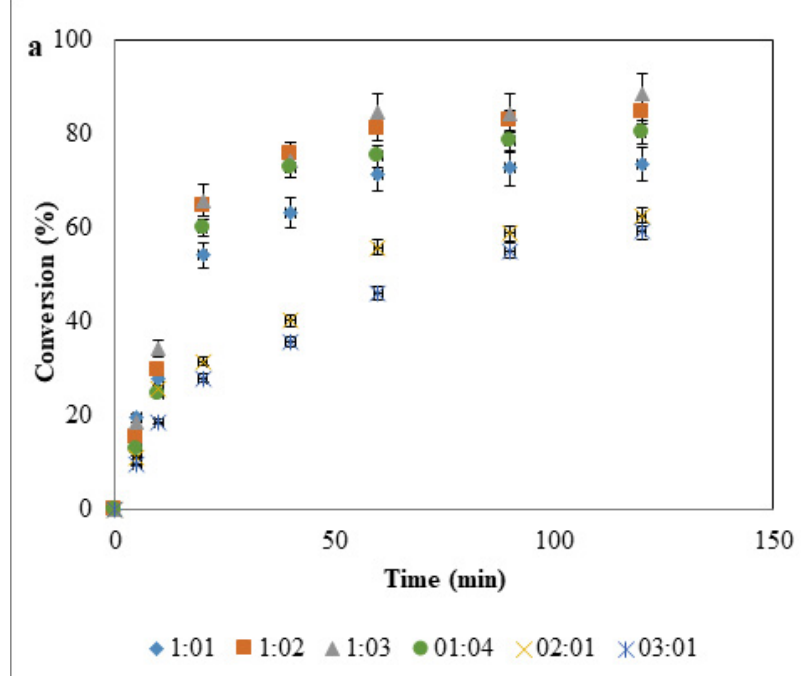

\subsubsection{Effect of speed of agitation}

The speed of agitation from $150 \mathrm{rpm}$ to $350 \mathrm{rpm}$ was varied by keeping other parameters constant. The $250 \mathrm{rpm}$ was selected as the optimum speed of agitation with maximum conversion 88.57\% (Figure S3). Beyond $250 \mathrm{rpm}$, there was marginal conversion and the conversion graph shows plateau. This is indicated that the external mass transfer resistance is negligible at $250 \mathrm{rpm}$ and reaction becomes rate controlled.

It was observed that the conversion was significantly affected by substrate ratio, enzyme loading and temperature which can be optimized through RSM, whereas the reaction time and speed of agitation were chosen constant as $120 \mathrm{~min}$ and $250 \mathrm{rpm}$, respectively. The three-level-three-factor CCD requiring 20 experiments were employed to optimize the significant parameters (Table 2). The variables and their levels selected for the study of ethyl hexanoate synthesis were hexanoic acid to ethanol molar ratio (1:2 to 1:4), enzyme dosage (1 to $3 \%$ $\mathrm{w} / \mathrm{w})$, and reaction temperature $\left(40\right.$ to $\left.60^{\circ} \mathrm{C}\right)$.

\subsection{Model fitting and Analysis of Variance (ANOVA)}

RSM is a useful statistical technique used to optimize the various parameters for synthesis of ethyl hexanoate. The composition of various runs of the CCD (in term of coded factors), actual and predicted responses for synthesis of ethyl hexanoate is given in Table 2. All 20 experiments were carried out in random order to avoid bias. The ANOVA done after fitting the data to the various models (linear, two factorial, quadratic and cubic) showed that

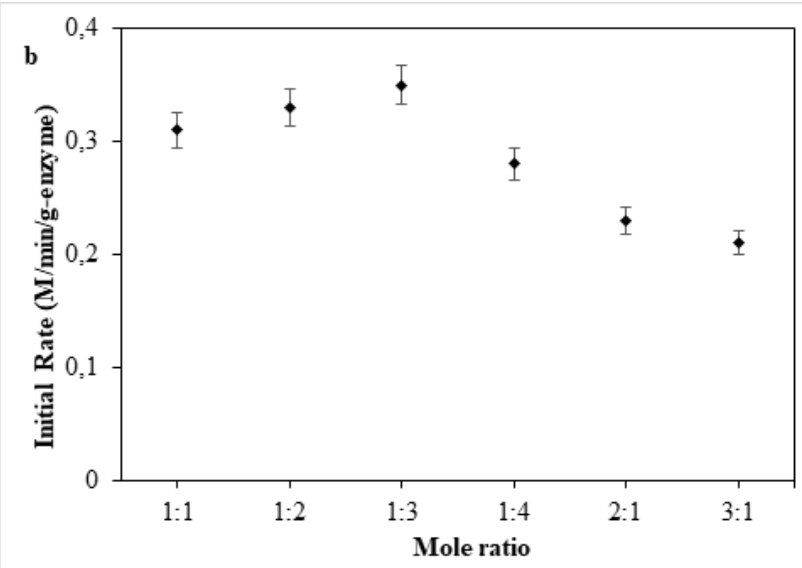

Figure 3.(a) \% Conversion vs. time and (b) Initial rate vs. mole ratio (hexanoic acid to ethanol from 1:1 to 3:1) under following conditions: time- $120 \mathrm{~min}$, temperature- $50^{\circ} \mathrm{C}$, enzyme loading - $2 \% \mathrm{w} / \mathrm{w}$, speed of agitation- $250 \mathrm{rpm}$ and molecular sieves- $6 \% \mathrm{w} / \mathrm{w}$. 
the esterification reaction carried out for the formation of ethyl hexanoate was best described by a quadratic model equation. The equation of the model obtained based on the coded values is as follows:

$Y=89.88+3.28 * A+1.51 * B+0.93 * C-1.12 * A * B-0.55 * A * C+0.16 * B$ $* C-2.73 * A^{2}-0.88 * B^{2}-1.84 * C^{2}$

[3]

Here, $\mathrm{Y}$ represents $\%$ Conversion, $\mathrm{A}=$ Molar ratio (MR), $\mathrm{B}=$ Enzyme (E) and $\mathrm{C}=$ Temperature (TEMP).

The ANOVA for the model is as shown in the Table 3. The acceptability and significance of the model are generally checked by model $\mathrm{F}$ values, $\mathrm{p}$-values and adequate precision. According to the Table 3, the F-value (29.26) with a p-value less than 0.0001 implies that the model is significant. There is only a $0.01 \%$ chance that a "Model F-Value" this large could occur due to noise. Values of "Prob > F" less than 0.0500 indicates model terms are significant. The coefficient of determination $\left(R^{2}\right)$ turned out to be 0.9634 , which showed the suitability of the model to represent the relationship between the reaction parameters. The value of $\mathrm{R}^{2} a d j$ was 0.9305 indicating the significance of the model. Adequate precision gives the

Table 2. Composition of the various runs of the CCD (in term of coded factors), actual, and predicted responses for synthesis of ethyl hexanoate.

\begin{tabular}{|c|c|c|c|c|c|}
\hline \multirow[t]{2}{*}{ Exp. No. } & \multicolumn{5}{|c|}{ Variables } \\
\hline & $\begin{array}{l}\text { Molar } \\
\text { Ratio }\end{array}$ & $\begin{array}{l}\text { Enzyme } \\
(\%)\end{array}$ & $\begin{array}{l}\text { Temperature } \\
(\stackrel{\circ}{C})\end{array}$ & $\begin{array}{l}\text { Actual } \\
\text { Conversion (\%) }\end{array}$ & $\begin{array}{l}\text { Predicted } \\
\text { Conversion (\%) }\end{array}$ \\
\hline 1 & $1: 2$ & 1.50 & 40.00 & 76.77 & 77.56 \\
\hline 2 & $1: 4$ & 1.50 & 40.00 & 87.63 & 87.46 \\
\hline 3 & $1: 2$ & 2.50 & 40.00 & 81.50 & 82.50 \\
\hline 4 & $1: 4$ & 2.50 & 40.00 & 86.88 & 87.91 \\
\hline 5 & $1: 2$ & 1.50 & 60.00 & 80.12 & 80.19 \\
\hline 6 & $1: 4$ & 1.50 & 60.00 & 87.80 & 87.90 \\
\hline 7 & $1: 2$ & 2.50 & 60.00 & 84.50 & 85.77 \\
\hline 8 & $1: 4$ & 2.50 & 60.00 & 88.68 & 88.99 \\
\hline 9 & $1: 1.32$ & 2.00 & 50.00 & 78.98 & 77.65 \\
\hline 10 & $1: 4.68$ & 2.00 & 50.00 & 88.91 & 88.68 \\
\hline 11 & $1: 3$ & 1.16 & 50.00 & 84.80 & 84.86 \\
\hline 12 & $1: 3$ & 2.84 & 50.00 & 90.54 & 89.92 \\
\hline 13 & $1: 3$ & 2.00 & 33.18 & 84.17 & 83.12 \\
\hline 14 & $1: 3$ & 2.00 & 66.82 & 86.74 & 86.23 \\
\hline 15 & $1: 3$ & 2.00 & 50.00 & 90.11 & 89.88 \\
\hline 16 & $1: 3$ & 2.00 & 50.00 & 89.12 & 89.88 \\
\hline 17 & $1: 3$ & 2.00 & 50.00 & 90.27 & 89.88 \\
\hline 18 & $1: 3$ & 2.00 & 50.00 & 89.97 & 89.88 \\
\hline 19 & $1: 3$ & 2.00 & 50.00 & 90.58 & 89.88 \\
\hline 20 & $1: 3$ & 2.00 & 50.00 & 88.98 & 89.88 \\
\hline
\end{tabular}

Table 3. ANOVA test for percentage conversion of ethyl hexanoate.

\begin{tabular}{|c|c|c|c|c|c|}
\hline Source & $\begin{array}{l}\text { Sum of } \\
\text { Squares }\end{array}$ & DF & $\begin{array}{l}\text { Mean } \\
\text { Square }\end{array}$ & F value & Prob $>$ F \\
\hline Model & 324.80 & 9 & 36.09 & 29.26 & $<0.0001$ significant \\
\hline$A$ & 146.96 & 1 & 146.96 & 119.16 & $<0.0001$ \\
\hline B & 31.00 & 1 & 31.00 & 25.13 & 0.0005 \\
\hline $\mathrm{C}$ & 11.70 & 1 & 11.70 & 9.49 & 0.0116 \\
\hline $\mathrm{A} 2$ & 81.28 & 1 & 81.28 & 65.90 & $<0.0001$ \\
\hline B2 & 11.19 & 1 & 11.19 & 9.07 & 0.0131 \\
\hline $\mathrm{C} 2$ & 48.84 & 1 & 48.84 & 39.60 & $<0.0001$ \\
\hline$A B$ & 10.08 & 1 & 10.08 & 8.17 & 0.0170 \\
\hline $\mathrm{AC}$ & 2.40 & 1 & 2.40 & 1.94 & 0.1934 \\
\hline $\mathrm{BC}$ & 0.20 & 1 & 0.20 & 0.17 & 0.6922 \\
\hline Residual & 12.33 & 10 & 1.23 & & \\
\hline Lack of fit & 10.25 & 5 & 2.05 & 4.93 & 0.0524 not significant \\
\hline Pure Error & 2.08 & 5 & 0.42 & & \\
\hline Cor Total & 337.13 & 19 & & & \\
\hline
\end{tabular}


measure of the signal-to-noise ratio and should preferably be greater than 4 . In the present work, the ratio has a value of 15.741, which confirms that the models can be successfully used for the enzymatic synthesis of ethyl hexanoate. Table 3 gives the values of the model terms. Out of them, the terms A, B, C, A2, B2, C2, AB are seen to be significant. Values greater than 0.10 indicates that the model terms are not significant. Figure 4 shows the normal probability plot which describes the relationship between the actual values of conversion yield and those predicted by the model. A linear distribution was inspected, which gave the confirmation of a well-fitting model. The effect of reaction parameters on the ester synthesis was then studied using equation [3].

\subsection{Effect of parameters and optimum conditions}

According to ANOVA, the relationships between temperature and other reaction parameters were studied by a series of contour plots which were generated from the predicted model. The plots efficiently indicate the effect of the reaction parameters on the synthesis of the ester. Figure 5 depicts the combined effect of the enzyme loading and the molar ratio on the $\%$ conversion at a constant temperature of $50{ }^{\circ} \mathrm{C}, 250 \mathrm{rpm}$ and $120 \mathrm{~min}$ reaction time. The lower conversion was observed when the enzyme loading was $1.5 \%$ and the molar ratio was $1: 2$. While an increase in enzyme loading from 1.5 to $2 \%$, increases the percentage conversion. However, further increase in enzyme loading decreases the percentage conversion with an increase in the alcohol to acid ratio. Alcohols have been reported to be competitive inhibitors of lipases, so an increase in ethanol amount would inhibit the enzyme activity and decrease the percentage conversion of ethyl hexanoate [29,31]. By the inspection of the plot, we can understand that a maximum conversion $(\sim 89 \%)$ was obtained with $2 \%$ of enzyme loading and acid to alcohol molar ratio in the range 1:3-3.5.

Figure 6 depicts the effect of temperature, enzyme loading and their mutual interaction on \% conversion of ethyl hexanoate at substrate ratio $1: 3$ to $250 \mathrm{rpm}$ and 120 min reaction time. It is well known that the collisions between enzyme and substrate molecules increase with an increase in temperature that gives a higher reaction rate and conversion. It was observed that the conversion increases with enzyme loading from $1-2 \%(\mathrm{w} / \mathrm{w})$ due to an increase in the number of active sites [32]. The highest conversion could be attained when the enzymeloading was taken as $2 \%$ at temperature of $50{ }^{\circ} \mathrm{C}$. The rate of reaction was found to decrease with an increase in temperature from 50 to 60 으 because of disruption of enzyme tertiary structure and denaturation at higher temperature [33, 34]. However, with an increase in the enzyme amount above 2
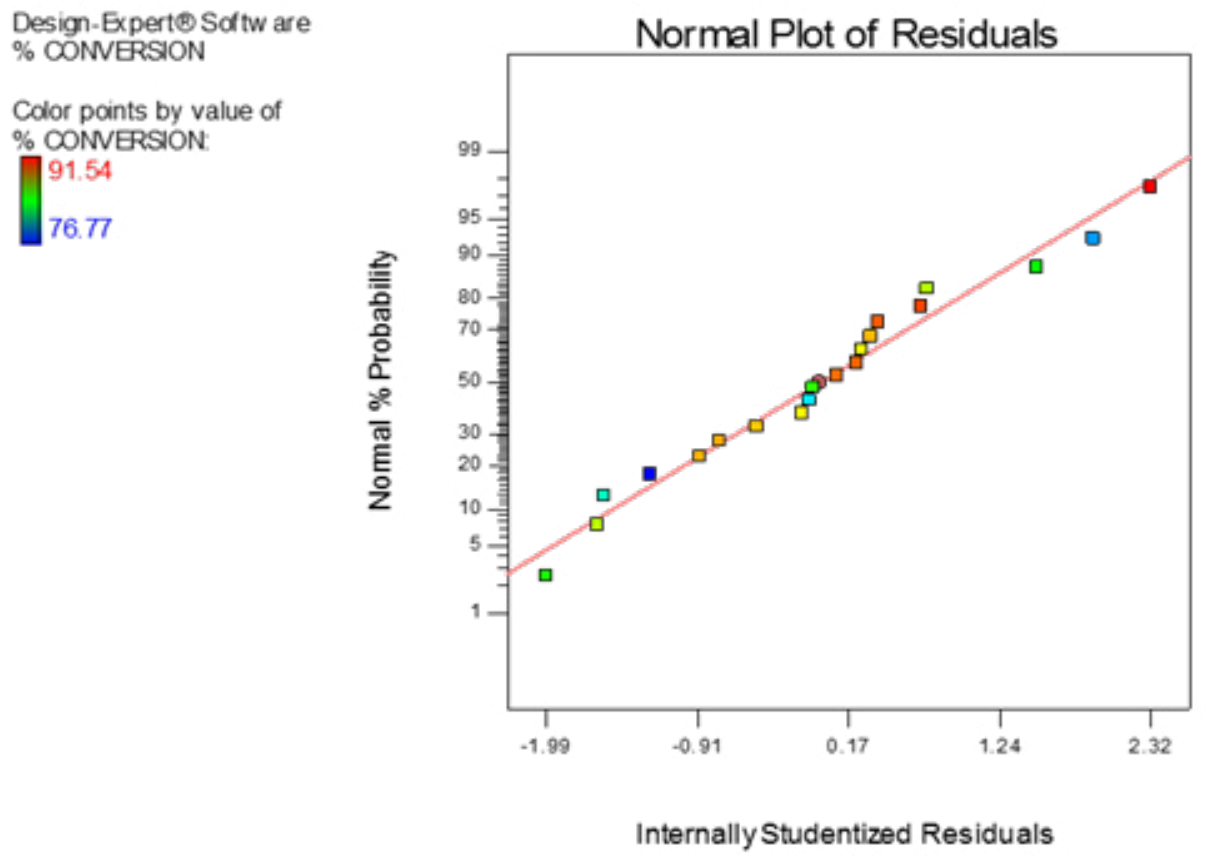

Figure 4. Normal probability plot of studentized residuals for the purpose of checking the normality of the residues 

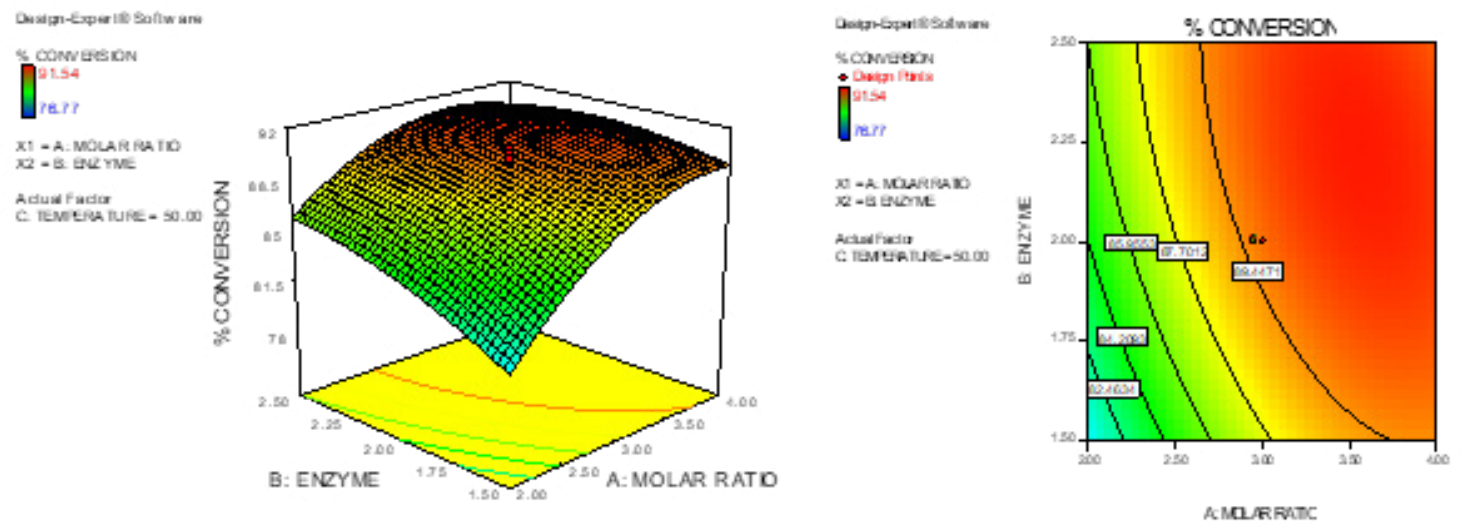

Figure 5. Contour plot showing the relationship between the enzyme lading, molar ratio and the \% conversion
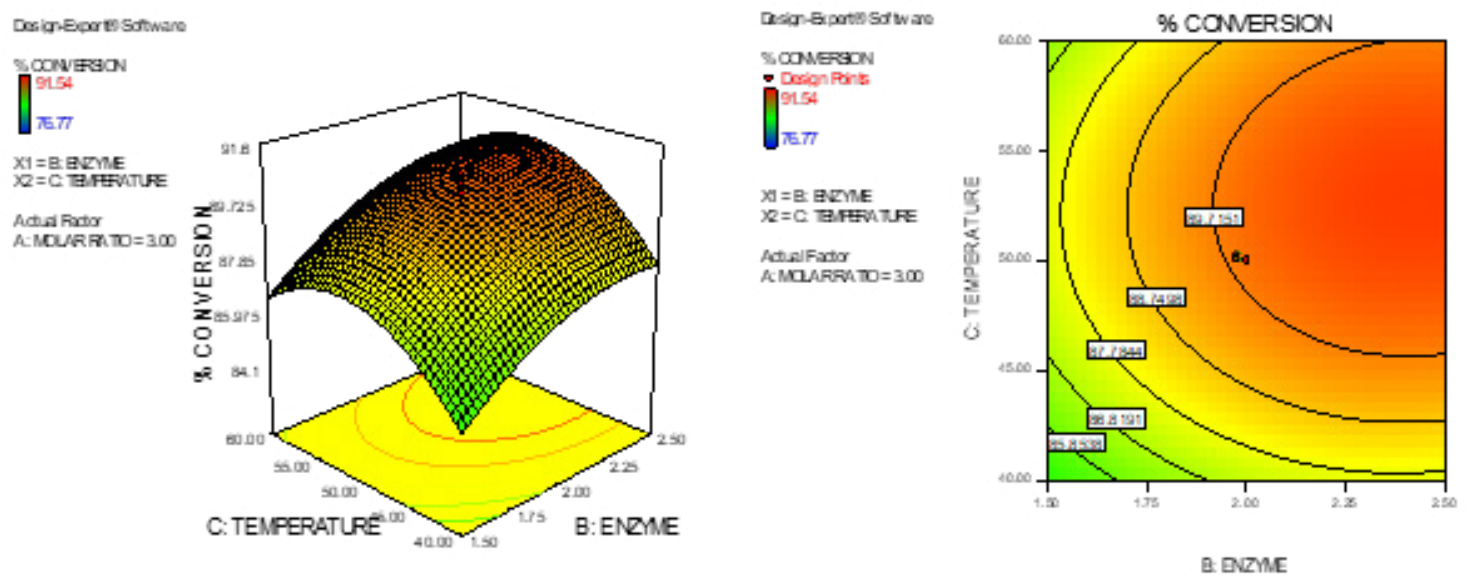

Figure 6. Contour plot showing the relationship between the temperature, enzyme loading and the \% conversion

$\%$, there was no considerable increase in the percentage conversion due to unavailability of the substrate.

Figure 7 shows the combined effect of temperature and molar ratio on the percentage conversion at $2 \%$ $(\mathrm{w} / \mathrm{w})$ enzyme loading in $120 \mathrm{~min}$. An increase in ethanol amount (up to acid to alcohol 1:3) increases the percentage conversion of ester. Thus, a higher molar ratio of acid to alcohol (1:3) was chosen so that the alcohol can act as a solvent for the acid. The excess alcohol can reduce the viscosity of the substrate and enhance the rate of reaction. Further increase in the amount of alcohol (1:4) decreases the percentage conversion at high temperature. This indicates that ethanol is a terminal inhibitor of the enzyme and its effect can increase at high temperature $[35,36]$. Table 4 shows the multiple solutions to the range of input parameters and responses with desirability for enzymatic synthesis of ethyl hexanoate.

\subsection{Optimum Conditions and validation of model}

The maximum conversion predicted by design expert software was $90.99 \%$ at the conditions of $48.83^{\circ} \mathrm{C}$, $2.35 \%$ enzyme amount and 1:3.39 acid: alcohol molar ratio in 120 min reaction time. However, the conversion of $90.54 \%$ was obtained when the experiment was conducted at similar conditions. In order to validate the predictions made by the model, experiments were conducted in triplicate at the optimum process conditions given by the model for $120 \mathrm{~min}$. As the experimental conversion obtained under these conditions was $\sim 90.54 \%$, which is very close to the maximum predicted value of $90.99 \%$, it can be concluded that model Eqn. (2) predicts the percentage conversion very appropriately. 

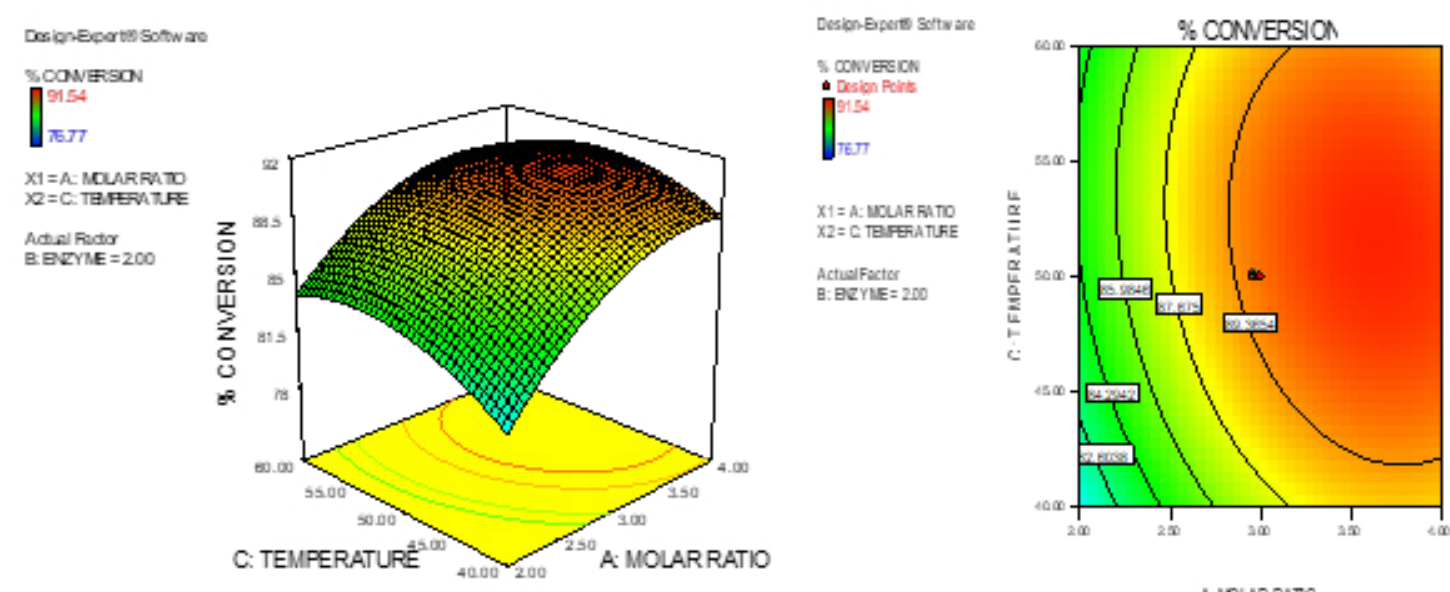

A.MOLAR RATO

Figure 7. Contour plot showing the relationship between temperature, molar ratio and the \% conversion

Table 4. Solution to the range of input parameters and responses with desirability for enzymatic synthesis of ethyl hexanoate

\begin{tabular}{llllll}
\hline $\begin{array}{l}\text { Solutions } \\
\text { Number }\end{array}$ & $\begin{array}{l}\text { Molar Ratio } \\
(\mathbf{M})\end{array}$ & $\begin{array}{l}\text { Enzyme Loading } \\
(\%)\end{array}$ & $\begin{array}{l}\text { Temperature } \\
\left({ }^{\circ} \mathrm{C}\right)\end{array}$ & Percentage Conversion (\%) & Desirability \\
\hline 1 & $1: 3.39$ & 2.35 & 48.83 & 90.99 & 1 \\
2 & $1: 3.29$ & 2.29 & 48.28 & 90.82 & 1 \\
3 & $1: 2.84$ & 2.23 & 48.03 & 89.61 & 1 \\
4 & $1: 3.40$ & 1.63 & 52.46 & 89.58 & 1 \\
5 & $1: 2.59$ & 2.31 & 53.14 & 89.23 & 1 \\
\hline
\end{tabular}

\subsection{Effect of activation energy and thermo- dynamic parameter}

The Arrhenius plot (Figure 8) was plotted in the range of $313-333 \mathrm{~K}$ to find the activation energy as $25.76 \mathrm{~kJ} / \mathrm{mol}(6.15$ $\mathrm{kcal} / \mathrm{mol})$. This value lies within the distinctive range i.e. $5-15 \mathrm{kcal} / \mathrm{mol}$ of enzyme catalytic reaction [37]. Figure 8 showed an acceptable linear fit and $\Delta \mathrm{H}$ was appraised from the slope of the curves and $\Delta S$ was calculated from the intercepts. The values of $\Delta \mathrm{H}, \Delta \mathrm{S}$ and $\Delta \mathrm{G}$ obtained from the experimental data have been shown in Table 5. The negative value of $\Delta S$ indicates that the product is more ordered as compared to the reaction. The positive value of $\Delta \mathrm{G}$ indicates that the reaction was non-spontaneous in nature. The positive value of $\Delta \mathrm{H}$ shows that external heat

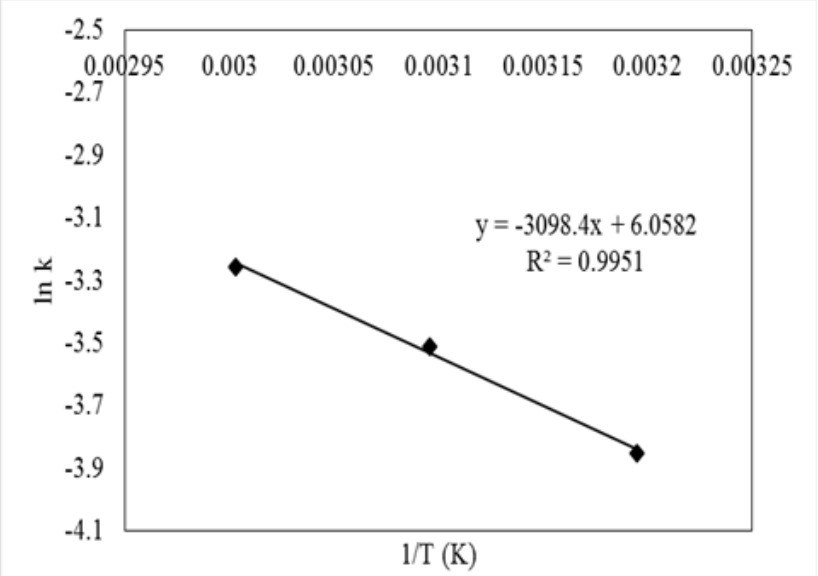

Figure 8. Arrhenius plot of $\ln (k)$ vs $1 / T$ for the esterification for hexanoic acid to ethanol molar ratio of $1: 3$ with $2 \%(w / w)$ enzyme loading

Table 5: Thermodynamic parameters for enzymatic esterification reaction.

\begin{tabular}{|c|c|c|c|c|c|}
\hline \multirow{2}{*}{$\frac{\text { Term }}{\text { Ea }}$} & \multirow{2}{*}{$\begin{array}{l}\text { Description } \\
\text { Energy of activation }(\mathrm{kJ} / \mathrm{mol})\end{array}$} & \multicolumn{2}{|c|}{ Values for esterification (Present work) } & \multicolumn{2}{|c|}{ Ferrão-Gonzales et al. (2011) } \\
\hline & & 25.76 & & & \\
\hline & & $313 \mathrm{~K}$ & $323 \mathrm{~K}$ & $333 \mathrm{~K}$ & \\
\hline$\Delta \mathrm{H}$ & Enthalpy of activation (kJ/mol) & 23.16 & 23.08 & 22.99 & 11.1 \\
\hline$\Delta \mathrm{S}$ & Entropy of activation $(\mathrm{kJ} / \mathrm{mol} / \mathrm{K})$ & -0.277 & -0.275 & -0.273 & -98.0 \\
\hline$\Delta \mathrm{G}$ & Gibb's free energy (kJ/mol) & 109.97 & 111.82 & 113.88 & 109 \\
\hline
\end{tabular}


is required to carry the reactants towards the transition state so as to form the products. The positive values of $\Delta \mathrm{H}$ for enzymatic reactions illustrate the endothermic nature of the reactions. The similar trends for thermodynamic parameters were observed by the Ferrão-Gonzales et al. during the enzymatic production of ethyl esters [38]. The reaction temperature had a strong influence on the rate of ester production because of endothermic nature of the reaction. Therefore, a suitable reaction temperature needs to be selected for maximum conversion of ester.

\section{Kinetic analysis of the process based on initial rate measurement}

The effect of substrate concentrations; i.e. ethanol and hexanoic acid on the rate of reaction by using Novozym 435 in solvent free condition was investigated. The Ping Pong Bi Bi and Ordered Bi Bi mechanisms were studied. The initial reaction rates were appraised from the slope of ethanol or hexanoic acid concentration versus time plots [29]. Figure 3(b) shows the initial rate verses concentration of acid using experimental data. As hexanoic acid concentration increased from 2.79 M (B:A=4:1) to $6.93 \mathrm{M}$ (B:A = 1:3); the initial velocity reached its highest value ( $0.35 \mathrm{M} / \mathrm{min} / \mathrm{g}$ catalyst) from $0.31 \mathrm{Mol} / \mathrm{min} / \mathrm{g}$ enzyme and again started decreasing. The kinetic constants were evaluated by non-linear regression with minimization of sum of square of errors (SSE) using Microsoft Excel 2013 [34]. It was observed that SSE was minimum for the Ping Pong Bi Bi model than that of Ordered Bi Bi. Chowdary et al. [20] discussed the synthesis of ethyl hexanote by transesterification of ethyl caprate with hexanoic acid in $n$-hexane using an immobilized Rhizomucor miehei lipase (RML) for which they had found a Ping Pong Bi Bi mechanism with competitive inhibition by hexanoic acid. In the present work it was observed that the reaction mechanism follows Ping Pong $\mathrm{Bi} \mathrm{Bi}$ mechanism with inhibition of ethanol above certain concentrations and clear inhibition by hexanoic acid. The kinetic constants for the Ping Pong $\mathrm{Bi} \mathrm{Bi}$ and Ordered $\mathrm{Bi} \mathrm{Bi}$ are shown in the Table 6 and Figure 9. The best fit model parameters were obtained by non-linear regression for Ping Pong Bi Bi mechanism with acid and alcohol inhibition were $\mathrm{V}_{\max }=6.29 \times 10^{2} \mathrm{M} / \mathrm{min} / \mathrm{g}$ enzyme, $\mathrm{K}_{\mathrm{A}}=0.0883 \mathrm{M}$, $\mathrm{K}_{\mathrm{B}}=0.0651 \mathrm{M}, \mathrm{K}_{\mathrm{iA}}=0.0022 \mathrm{M}, \mathrm{K}_{\mathrm{iB}}=0.0088 \mathrm{M}$ and SSE $=0.58 \times 10^{-2}$. The predicted initial rates were calculated by using the parameters in Table 6 for the ternary model and are compared against the experimental values for different substrate concentrations (Figure 10). There was an excellent match for Ping Pong Bi Bi mechanism between predicted and experimental, proving the validity of the model.

\section{Conclusion}

Ethyl hexanoate ester synthesis using immobilized Candida antarctica lipase was successfully performed and the modelling of the synthesis was done by central

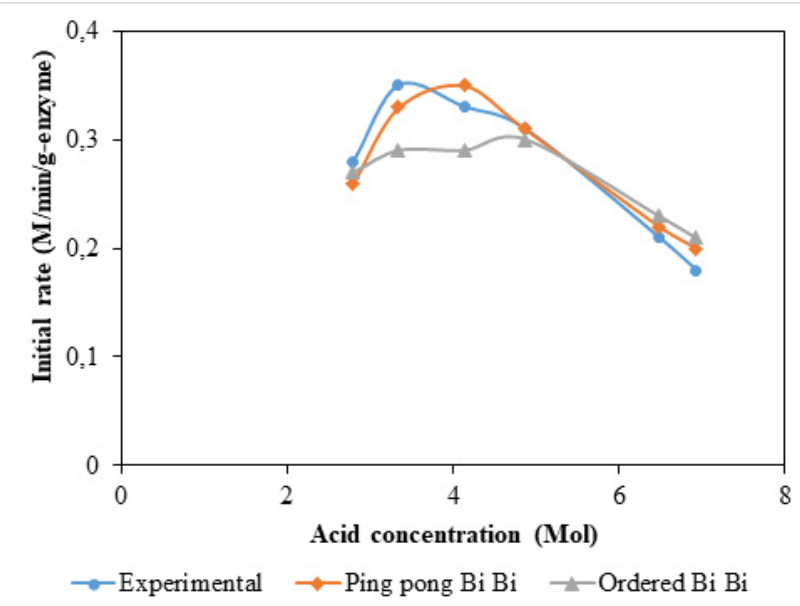

Figure 9. Comparison of calculated initial rates by the all mechanism with the experimental values.

Table 6: Comparison of calculated evaluated kinetic parameters for all mechanisms.

\begin{tabular}{llll}
\hline Model/Parameters & Ordered Bi-Bi (present work) & Ping Pong Bi-Bi (present work) & Chowdary et. al. (2003) \\
\hline Vmax (M/min/g-enzyme) & 12.434 & $6.29 \times 10^{2}$ & 1.861 \\
KA (M) & $1.6 \times 10^{-05}$ & 0.0883 & 0.08468 \\
KB (M) & 5.1493 & 0.0651 & 0.0135 \\
KiA (M) & 0.0086 & 0.0022 & 0.550 \\
KiB (M) & - & 0.0088 & 3.07 \\
Ki (M) & 1.6870 & - & - \\
SSE & 0.017 & $0.58 \times 10^{-2}$ & \\
\hline
\end{tabular}




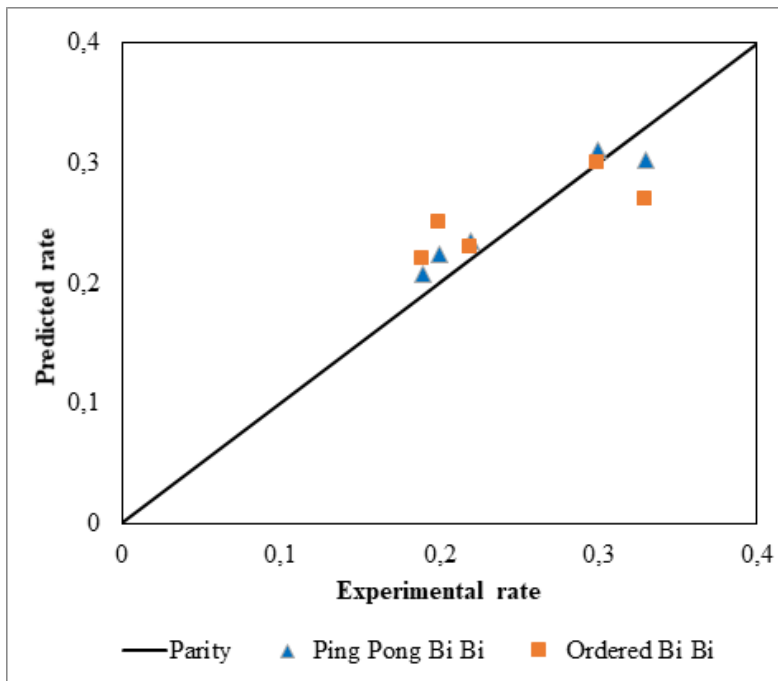

Figure 10. Parity plot for enzymatic kinetic model

composite design and response surface methodology. The $\mathrm{R}^{2}$ obtained after the model fitting was 0.96 and ANOVA implied that the model had satisfactorily indicated and explained the real relationship of the reaction parameters. As compared to a one factor at a time method, the statistical optimization method gave $2-3 \%$ increase in conversion. The molar ratio, enzyme loading and temperature illustrated a significant effect on the esterification reaction. The activation energy was calculated as 25.76 $\mathrm{kJ} / \mathrm{mol}$ which is in the range of enzymatic reactions. The thermodynamic parameters predict the non-spontaneous and endothermic nature of enzymatic synthesis of ethyl hexanoate. The esterification reaction seems to follow a Ping Pong Bi Bi mechanism with competitive inhibition by acid and alcohol. Overall, the data obtained here will be further useful for future up-scaling of the enzyme catalysed of pineapple flavour.

\section{References}

[1] K.P. Dhake, D.D. Thakare, B.M. Bhanage, Lipase: A potential biocatalyst for the synthesis of valuable flavour and fragrance ester compounds, Flavour Fragr. J., 2013, 28, 71-83.

[2] G.D. Yadav, S. Devendran, Lipase catalyzed synthesis of cinnamyl acetate via transesterification in non-aqueous medium, Process Biochem., 2012, 47, 496-502.

[3] A. Richetti, S.G.F. Leite, O. a C. Antunes, L. a. Lerin, R.M. Dallago, D. Emmerich, et al., Assessment of process variables on 2-ethylhexyl palmitate production using Novozym 435 as catalyst in a solvent-free system, Bioprocess Biosyst Eng., 2010, 33, 331-337.

[4] L. a. Lerin, R. a. Loss, D. Remonatto, M.C. Zenevicz, M. Balen, V.O. Netto, et al., A review on lipase-catalyzed reactions in ultrasound-assisted systems, Bioprocess Biosyst. Eng., 2014, 37, 2381-2394.
[5] Y. Xu, D. Wang, X.Q. Mu, G.A. Zhao, K.C. Zhang, Biosynthesis of ethyl esters of short-chain fatty acids using whole-cell lipase from Rhizopus chinesis CCTCC M201021 in non-aqueous phase, J. Mol. Catal. B: Enzym., 2002, 18, 29-37.

[6] R. Dave, D. Madamwar, Esterification in organic solvents by lipase immobilized in polymer of PVA-alginate-boric acid, Process Biochem., 2006, 41, 951-955.

[7] G. Yadav, P. Mehta, Heterogeneous catalysis in esterification reactions: preparation of phenethyl acetate and cyclohexyl acetate by using a variety of solid acidic catalysts, Ind. Eng. Chem. Res., 1994, 33, 2198-2208.

[8] J. Wang, S. Gu, N. Pang, F. Wang, F. Wu, A study of the esterification of caffeic acid with methanol using $p$-toluenesulfonic acid as a catalyst, J. Serb. Chem. Soc., 2013, 78, 1023-1034.

[9] M.C.C. Corradini, R.A.B. Gomes, J.H.H. Luiz, A.A. Mendes, Optimization of Enzymatic Synthesis of $n$-Propyl Acetate (Fruit Flavor Ester) - Effect of the Support on the Properties of Biocatalysts, Chem. Engg. Commun., 2016, 203, 1432-1442.

[10] S. Serra, C. Fuganti, E. Brenna, Biocatalytic preparation of natural flavours and fragrances., Trends Biotech., 2005, 23, 193-8.

[11] S. Ferreira-Dias, G. Sandoval, F. Plou, F. Valero, The potential use of lipases in the production of fatty acid derivatives for the food and nutraceutical industries, Electron J Biotechnol., 2013, $16,1-34$.

[12] G. Sandoval, J.S. Condoret, P. Monsan, A. Marty, Esterification by immobilized lipase in solvent-free media: Kinetic and thermodynamic arguments, Biotechnol. Bioeng., 2002, 78, 313-320.

[13] Y. Shimada, Y. Watanabe, A. Sugihara, T. Baba, T. Ooguri, S. Moriyama, et al., Ethyl esterification of docosahexaenoic acid in an organic solvent-free system with immobilized Candida antarctica lipase, J Biosci Bioeng., 2001, 92, 19-23.

[14] C. Grosso, S. Ferreira-Dias, P. Pires-Cabral, Modelling and optimization of ethyl butyrate production catalysed by Rhizopus oryzae lipase, J. Food Eng. 115 (2013) 475-480.

[15] C. Beula, P.S.T. Sai, Kinetics of Esterification of Palmitic acid with Ethanol- Optimization Using Statistical Design of Experiments, Int J Chem Eng Appl., 2013, 4, 388-392.

[16] A.S.G. Lorenzoni, N.G. Graebin, A.B. Martins, R. FernandezLafuente, M. a. Záchia Ayub, R.C. Rodrigues, Optimization of pineapple flavour synthesis by esterification catalysed by immobilized lipase from Rhizomucor miehei, Flavour Fragr. J., 2012, 27, 196-200.

[17] A. Guvenc, N. Kapucu, E. Bayraktar, U. Mehmetoglu, Optimization of the enzymatic production of isoamyl acetate with Novozym 435 from Candida antarctica, Chem. Engg. Commun., 2003, 190, 948-961.

[18] M.A. Bezerra, R.E. Santelli, E.P. Oliveira, L.S. Villar, L. a. Escaleira, Response surface methodology (RSM) as a tool for optimization in analytical chemistry, Talanta., 2008, 76, 965-977.

[19] N. Aslan, Y. Cebeci, Application of Box-Behnken design and response surface methodology for modeling of some Turkish coals, Fuel., 2007, 86, 90-97.

[20] G. V. Chowdary, S.G. Prapulla, Enzymatic synthesis of ethyl hexanoate by transesterification, Int J Food Sci Technol., 2003, 38, 127-133.

[21] S.Y. Han, Z.Y. Pan, D.F. Huang, M. Ueda, X.N. Wang, Y. Lin, Highly efficient synthesis of ethyl hexanoate catalyzed by 
CALB-displaying Saccharomyces cerevisiae whole-cells in non-aqueous phase, J. Mol. Catal B: Enzym., 2009, 59, 168-172.

[22] Z. Jin, J. Ntwali, S. Han, S. Zheng, Y. Lin, Production of flavor esters catalyzed by CALB-displaying Pichia pastoris whole-cells in a batch reactor, J. Biotechnol., 2012, 159, 108-114.

[23] K.C. Badgujar, P.A. Pai, B.M. Bhanage, Enhanced biocatalytic activity of immobilized Pseudomonas cepacia lipase under sonicated condition, Bioprocess Biosyst Eng., 2016, 39, 211-221.

[24] B. Manohar, S. Divakar, Application of central composite rotatable design to lipase catalysed synthesis of m-cresyl acetate, World J Microbiol Biotechnol., 2002, 18, 745-751.

[25] D.-H. Zhang, C. Li, G.-Y. Zhi, Kinetic and thermodynamic investigation of enzymatic L-ascorbyl acetate synthesis., J. Biotechnol., 2013, 168, 416-20.

[26] S. Chakma, V.S. Moholkar, Ultrasonics Sonochemistry Investigations in sono-enzymatic degradation of ibuprofen, Ultrason Sonochem., 2016, 29, 485-494.

[27] T.W. Charpe, V.K. Rathod, Biodiesel production using waste frying oil, Waste Manag., 2011, 31, 85-90.

[28] W.-J. Sun, H.-X. Zhao, F.-J. Cui, Y.-H. Li, S.-L. Yu, Q. Zhou, et al., D-isoascorbyl palmitate: lipase-catalyzed synthesis, structural characterization and process optimization using response surface methodology., Chem. Cent. J., 2013, 7, 114.

[29] S.D. Gawas, S. V. Jadhav, V.K. Rathod, Solvent Free Lipase Catalysed Synthesis of Ethyl Laurate: Optimization and Kinetic Studies, Appl. Biochem. Biotechnol., 2016, 180, 1428-1445.

[30] G.D. Yadav, P.S. Lathi, Intensification of enzymatic synthesis of propylene glycol monolaurate from 1, 2-propanediol and lauric acid under microwave irradiation : Kinetics of forward and reverse reactions, Enzyme Microb. Technol., 2006, 38, 814-820.

[31] J.M. Rodriguez-Nogales, E. Roura, E. Contreras, Biosynthesis of ethyl butyrate using immobilized lipase: a statistical approach, Process Biochem., 2005, 40, 63-68.
[32] N. Paroul, L.P. Grzegozeski, V. Chiaradia, H. Treichel, R.L. Cansian, J.V. Oliveira, et al., Solvent-free geranyl oleate production by enzymatic esterification, Bioprocess Biosys Eng., 2011, 34, 323-329.

[33] M.E. Peterson, R.M. Daniel, M.J. Danson, R. Eisenthal, The dependence of enzyme activity on temperature: determination and validation of parameters., Biochem. J., 2007, 402, 331-337.

[34] V. V. Kuperkar, V.G. Lade, A. Prakash, V.K. Rathod, Synthesis of isobutyl propionate using immobilized lipase in a solvent free system: Optimization and kinetic studies, J Mol Catal B: Enzym., 2014, 99, 143-149.

[35] K.K. Podkaminer, X. Shao, D. a Hogsett, L.R. Lynd, Enzyme inactivation by ethanol and development of a kinetic model for thermophilic simultaneous saccharification and fermentation at $50{ }^{\circ} \mathrm{C}$ with Thermoanaerobacterium saccharolyticum ALK2., Biotechnol. Bioeng., 2011, 108, 1268-78.

[36] M.L. Foresti, M. Luja, Computational Approach to Solvent-Free Synthesis of Ethyl Oleate Using Candida rugosa and Candida antarctica B Lipases . I Interfacial Activation and Substrate ( Ethanol, Oleic Acid ) Adsorption, Biomacromolecules., 2004, 5, 2366-2375.

[37] G.D. Yadav, K.M. Devi, Enzymatic synthesis of perlauric acid using Novozym 435, Biochem. Eng. J., 2002, 10, 93-101.

[38] A.D. Ferrão-Gonzales, I.C. Véras, F. a. L. Silva, H.M. Alvarez, V.H. Moreau, Thermodynamic analysis of the kinetics reactions of the production of FAME and FAEE using Novozyme 435 as catalyst, Fuel Process. Technol., 2011, 92, 1007-1011.

Supplemental Material: The online version of this article (DOI: 10.1515/boca-2018-0002) offers supplementary material. 